\title{
Influence of Aqueous Leaf Extract of Senna Alata L, Roxb. on the Germination and Seedling Growth of Beans, Maize and Groundnut
}

\author{
Osuagwu, G. G. E. Udogu, O. F*. Osuagwu, A. N. Uwakwe, A. E. \\ Department of Plant Science and Biotechnology, Michael Okpara University of Agriculture, \\ Umudike, Umuahia Abia State Nigeria.
}

\begin{abstract}
Plants extracts have been known to either promote or inhibit plant growth and germination. The influence of aqueous leaf extract of Senna alata (L.) Roxb on the germination and seedling growth of maize (Zea mays), Beans (Phaseolus vulgaris) and Groundnut (Arachis hypogea) were investigated. The experiment was carried out at Michael Okpara University of Agriculture Umudike, green house situated besides the University apex Library. The leaves of Senna alata were air dried, ground, mixed with water and then used for the treatment. Concentrated extracts and its dilutions 1:1, 1:2.5, 1:5 v/v was used as treatments and water served as control. Each treatment was replicated three times. The experiment was designed using Randomized Completely Block Design (RCBD) and the results obtained were statistically analyzed using ANOVA. The result obtained showed that all treatments significantly $(\mathrm{P}<0.05)$ inhibited germination in maize except for $1: 2.5$, which improved germination. Also, the treatments significantly $(\mathrm{P}<0.05)$ inhibited germination in beans except for treatments $1: 1$ and 1:5, which improved germination. However, all treatments significantly $(\mathrm{P}<0.05)$ improved germination in groundnut. There was significant increase $(\mathrm{P}<0.05)$ in plant height and dry weight of the plant compared with the control. This indicates that seedling growth of Beans, Maize and Groundnut were positively affected by the aqueous leaf extract of $S$. alata. High concentration of the extract leads to increased plant height and dry matter of the plant. Further study is needed to ascertain the bio-activity of $S$. alata.
\end{abstract}

Keywords: Influence, Aqeouos leaf extract, Germination.

DOI: $10.7176 / \mathrm{JBAH} / 9-24-04$

Publication date: December $31^{\text {st }} 2019$

\subsection{Introduction}

Plants compete with each other for light, water and nutrient. Production of secondary metabolites, accumulation and release of these compounds is one of several complex defense strategies that have been evolved by plants (Ercusli and Turkal, 1998; Jain, 2011). The phenomenon of allelopathy, where a plant's specie chemically interferes with the germination, growth or development of other plant species has been known for over 2000years. Any process involving secondary metabolites, produced by plants, micro-organisms, viruses and fungi that influences the growth and development of agricultural and biological systems (excluding animals), including positive and negative effects is called allelopathy (Torres et al., 1996).

Most crude plants extracts are classified as secondary plant metabolites which are biosynthetically derived from the primary metabolites of plants (Singh et al., 2010). The metabolites or chemical compounds are present in several parts of the plant that are known to interfere with seed germination and growth (Krus et al., 2000).

Many of these secondary metabolites may have either positive or negative effects on germination. Their effects on seedling growth can also be inhibitory or they improve crop growth of plants under observation (Gupta and Rana, 2007; Evans, 2002; Osuagwu, 2007; Agbagwa, 2014).

The germination of plant seeds have reported to be inhibited by aqueous extracts of plants material (AlLumaid and Warrang, 1998; Ben-Hammouda et al., 2001; Igbal et al., 2001; Okwulehie and Amazu, 2004; Osuagwu, 2007; Osuagwu and Ibeabuchi, 2010; Osuagwu and Anyanwu, 2014; Agbagwa, 2014).

Research findings have indicated that the seedling growth of plants is inhibited by aqueous leaf, stem and leaf extracts (Igbal et al., 2001; Okwulehie and Amazu, 2004; Osuagwu, 2007).

On the other hand, the stimulated seedling growth of plants has also been observed by scientists (Oudhia, 2001; Ben-Hammouda et al., 2001; Osuagwu and Anyanwu, 2014). Ben-Hammouda et al. (2001) observed that barley extracts stimulated the growth of derum wheat. Similar observation was made by Osuagwu (2007) who reported that the aqueous leaf extract of A. Lobata caused the stimulation of seedling growth Vigna unguiculata (cowpea) and Zea mays (maize).

\subsection{Materials and methods}

\subsection{Study area}

The field work was carried out between the months July to September 2015 in an experimental farm behind the Mushroom house of Michael Okpara University of Agriculture, Umudike (MOUAU). Umudike falls within the 
rainforest zone in South East agro-ecological zone of Nigeria with a daily mean temperature range of $23^{\circ} \mathrm{c}$ to $32^{\circ} \mathrm{c}$. It lies approximately at latitude $05^{0} 29^{1} \mathrm{~N}$, longitudes $07^{0} 32^{1} \mathrm{E}$.

\subsection{Plant materials}

Maize Samaza28 and beans Sampia7 seeds were obtained from the seed service unit of National Root Crop Research Institute Umudike (NRCRI) Abia State. Groundnut seeds were obtained from the commercial market of Ahiaeke, Umuahia, Abia state.

The seeds were tasted for viability (Agrawal, 1995) and were found satisfactory. Senna alata leaf was obtained from the forest strip behind the college of Natural Sciences, Michael Okpara University of agriculture, Umudike Abia State, Nigeria.

Preparation of Aqueous Extract; Senna alata leaf was collected and chopped into segments of about $0.5 \mathrm{~cm}$ (Hansen-Quartey et al., 1998). Aqueous extracts were made using the modified method of Agbagwa (2014). Approximately $300 \mathrm{~g}$ of plant materials was mixed with $100 \mathrm{ml}$ of distilled water after being blended with Corona Leadersy CIA.S.A113 blender; the supernatant was filtered through four layers of chess cloth. The filtrates obtained were taken as the original undiluted extracts. Three dilutions 1:1, 1:2.5 and 1:5 v/v of the original extracts were prepared by mixing the original extracts with distilled water (Osuagwu, 2007).

\subsection{Seed germination test}

Seed germination test was carried out by using Hansen -Quartey et al. (1998) method. The treatment constitute of the leaf extract of Senna alata in four dilutions (undiluted,1:1,1:2.5,1:5) and three plant species Maize (Zea mays), Groundnuut (Arachis hypogea) and Beans (Phaseolus vulgaris). Distilled water was used as control in all the treatments. Fifteen seeds were placed between four filter paper discs in covered petri-dishes (12:5 in diameter) and kept moist by applying $1.5 \mathrm{ml}$ of the appropriate extracts once in two days.

The petri dishes were placed on the laboratory working bench (table) in the plant science and biotechnology laboratory at room temperature. Seeds with radical of $2 \mathrm{~mm}$ were observed to have germinated (Sahid and Sugau, 1993)

Observations were recorded for ten days after 10 days; the total number of seeds in each treatment was expressed as the percentage of the total number of seeds.

\subsection{Seedling growth test}

Thirty (30) planting buckets (pots) were filled with soil and placed in the green house of college of soil science, Michael Okpara University of Agriculture, Umudike. Four seeds of each plant species were sown in each planting bucket.

After seedling emergence, they were thinned to three seedlings per planting bucket. $15 \mathrm{ml}$ of extracts were applied through foliar spray using a small hand rubber sprayer on each of the seedling twice a week for 28 days. Plant height and dry weight of each seedling were determined at harvest.

Measurement of plant height was done using a $50 \mathrm{~cm}$ wooden ruler. To determine the dry weight of the seedlings, the seedlings were pulled out and the roots were washed free of the soil. The seedlings were then dried in the oven at 70 degree Celsius for 36 hours. Each plant was weight with an electric sensitive balance and the weight recorded. The average weight of the plants in each planting bucket was used as mean for each treatment.

2.5. Statistical analysis

Analysis of variance (ANOVA) was used to test or analyze the data collected from both germination and seedling growth test and LSD at 0.05 probability level was used to determine the difference among the treatments. Students' T-test was used to compare effects of leaf extracts.

The experimental design used for this study was a complete Randomized Design with three replicates for each treatment.

\subsection{Results}

\subsection{The effects of leaf extracts in the germination of seeds}

Effects of aqueous leaf extract of Senna alata on percentage germination of seeds of maize, beans and groundnut. 
Table 1: showed the influence of aqueous leaf extracts of Senna alata on the germination of seeds of Maize, Beans, Groundnut.

\begin{tabular}{|l|l|l|l|}
\hline Concentration of extracts & $\begin{array}{l}\text { Zea mays } \\
\text { Maize }\end{array}$ & $\begin{array}{l}\text { Phaseolus vulgaris } \\
\text { Beans }\end{array}$ & $\begin{array}{l}\text { Arachis hypogea } \\
\text { Groundnut }\end{array}$ \\
\hline Undiluted & $33.33^{\mathrm{a}}$ & $57.78^{\mathrm{a}}$ & $28.89^{\mathrm{a}}$ \\
\hline $1: 1$ & $64.44^{\mathrm{b}}$ & $66.67^{\mathrm{a}}$ & $37.78^{\mathrm{a}}$ \\
\hline $1: 2.5$ & $86.67^{\mathrm{c}}$ & $53.33^{\mathrm{a}}$ & $42.22^{\mathrm{a}}$ \\
\hline $1: 5$ & $75.56^{\mathrm{bc}}$ & $68.89^{\mathrm{a}}$ & $28.89^{\mathrm{a}}$ \\
\hline Control & $82.22^{\mathrm{c}}$ & $64.44^{\mathrm{a}}$ & $15.56^{\mathrm{a}}$ \\
\hline LSD $(0.05)$ & 1.34 & 0.23 & 0.05 \\
\hline
\end{tabular}

From the table above, 1:2.5 concentration gave the highest percentage germination seeds of Maize $(86.67 \%)$ followed by the control $(82.22 \%)$ while lowest is the undiluted $(33.33 \%)$. The plant extract had significant effect on Zea mays germination.

In contrast, table 1 showed that the concentration of 1:5 gave the highest percentage of germinated Bean seeds $(68.89 \%)$ while lowest in 1:2.5 concentration. Furthermore, the table revealed that 1:2.5 concentration gave the highest germinated groundnut seeds $(42.22 \%)$ followed by $1: 1(37.78 \%)$ while lowest in the control $(15.56 \%)$. From the table 1 above, it can be deduced that undiluted extract of Senna alata had no significant effect on the germination of beans (Phaseolus vulgaris) and groundnut. Whereas, at the 1:2.5 concentration, the maize and groundnut seeds had improved germination but the bean seeds were reduced in size. The germination of the seeds of maize and beans was significantly $(\mathrm{p}<0.05)$ reduced by the leaf extract of Senna alata when treated with undiluted concentrations.

\subsection{Seedling growth test}

Table 2: Effects of aqueous leaf extracts of Senna alata on height $(\mathrm{Cm})$ of maize, beans and groundnut.

\begin{tabular}{|l|l|l|l|}
\hline Concentration of extracts & $\begin{array}{l}\text { Zea mays } \\
\text { Maize }\end{array}$ & $\begin{array}{l}\text { Phaseolus vulgaris } \\
\text { Beans }\end{array}$ & $\begin{array}{l}\text { Arachis hypogeal } \\
\text { Groundnut }\end{array}$ \\
\hline Undiluted & $43.33 \pm 17.84^{\mathrm{ab}}$ & $77.75 \pm 11.89^{\mathrm{a}}$ & $43.67 \pm 5.43^{\mathrm{b}}$ \\
\hline $1: 1$ & $59.50 \pm 12.34^{\mathrm{b}}$ & $94.75 \pm 27.50^{\mathrm{a}}$ & $49.25 \pm 4.57^{\mathrm{c}}$ \\
\hline $1: 2.5$ & $44.17 \pm 10.52^{\mathrm{ab}}$ & $76.67 \pm 39.81^{\mathrm{a}}$ & $37.75 \pm 4.70^{\mathrm{ab}}$ \\
\hline $1: 5$ & $39.53 \pm 12.57^{\mathrm{ab}}$ & $65.04 \pm 44.54^{\mathrm{a}}$ & $38.92 \pm 3.72^{\mathrm{b}}$ \\
\hline Control & $37.17 \pm 18.86^{\mathrm{a}}$ & $57.84 \pm 36.49^{\mathrm{a}}$ & $32.37 \pm 1.89^{\mathrm{a}}$ \\
\hline LSD $(0.05)$ & 0.57 & 0.10 & 0.18 \\
\hline
\end{tabular}

The information in Table 2, showed the influence of aqueous leaf extract of Senna alata on the seedling height of maize, beans and groundnut seeds. The table revealed that 1:1 concentration gave the highest height followed by the 1:2.5 concentration (59.50 and 44.17 respectively) in maize whereas the lowest in the control (37.17) in contrast, the table showed that 1:1 concentration gave the highest height in Bean seeds (94.75), followed by the undiluted (77.75) while lowest in the control (57.83). Furthermore, the table revealed that 1:1 concentration gave the highest seedling height of groundnut seeds (49.25) followed by undiluted (43.67) while the lowest in the control (32.38). The plant extract had significant effect on the height of maize and groundnut whereas there was no significant effect in beans.

From this, it can be deducted that leaf extract of Senna alata improves seedling growth with respect to height of maize, beans and groundnut.

Table 3: Effects of aqueous leaf extract of Senna alata on dry weight (g) of maize, beans and groundnut.

\begin{tabular}{|l|l|l|l|}
\hline Concentration of extracts & $\begin{array}{l}\text { Zea mays } \\
\text { Maize }\end{array}$ & $\begin{array}{l}\text { Phaseolus vulgaris } \\
\text { Beans }\end{array}$ & $\begin{array}{l}\text { Arachis hypogeal } \\
\text { Groundnut }\end{array}$ \\
\hline Undiluted & $4.57 \pm 2.27^{\mathrm{a}}$ & $1.49 \pm 0.44^{\mathrm{ab}}$ & $2.80 \pm 0.28^{\mathrm{a}}$ \\
\hline $1: 1$ & $4.39 \pm 0.83^{\mathrm{a}}$ & $1.92 \pm 0.55^{\mathrm{b}}$ & $3.22 \pm 0.42^{\mathrm{a}}$ \\
\hline $1: 2.5$ & $3.27 \pm 1.33^{\mathrm{a}}$ & $1.77 \pm 0.68^{\mathrm{ab}}$ & $2.74 \pm 0.70^{\mathrm{a}}$ \\
\hline $1: 5$ & $3.12+1.35^{\mathrm{a}}$ & $1.44 \pm 0.71^{\mathrm{a}}$ & $2.77 \pm 0.67^{\mathrm{a}}$ \\
\hline Control & $3.00 \pm 1.46^{\mathrm{a}}$ & $1.10 \pm 0.43^{\mathrm{a}}$ & $2.47 \pm 0.96^{\mathrm{a}}$ \\
\hline LSD $(0.05)$ & 0.12 & 0.27 & 0.11 \\
\hline
\end{tabular}

Table 3 showed the influence of aqueous leaf extract of Senna alata on the dry weights of maize, Beans and Groundnut seeds. The table revealed that the undiluted treatment gave the highest dry weight of maize seeds (4.57) followed by 1:1 (4.39) and lowest is control (3.00). In contrast, the table showed that 1:1 concentration gave the highest dry weight of Bean seeds (1.9) followed by 1:2.5 (1.77) while the lowest is control (1.10). Furthermore, the table revealed that 1:1 concentration gave the highest dry weight of Groundnut seeds (3.22) followed by undiluted (2.47). From this, it can be deducted that leaf extracts of Senna alata significantly improved the dry weight of seeds of Beans whereas there was no significant effect on the dry weight of maize and Groundnut. 


\subsection{Discussion, conclusion and recommendation \\ 4.1. Discussion}

Germination: The germination of the seeds of Maize and groundnut was significantly $(p<0.05)$ reduced by the leaf extract of Senna alata (table 1), whereas there was no significant effect on the germination of Phaseolus vulgaris. Germination of seeds was as low as $33.33 \%$ and $57.78 \%$ in Maize and Beans when treated with undiluted concentrations similar inhibition effects have been reported for Lantana alata and Chromolaena odorata extracts on Chinese cabbage (Brassica sineensis L.), Chilli (Capsicum purescence L.) and Grape (Brassica juncea) (Sahid and Sugau, 1993). Chromolaena odorata extracts also inhibited seed germination in maize and Cowpea (Okwulehie and Amazu, 2004).

Extracts of Aspilia (Pers) C.D. Adams, Emilia sonchifolia (L) D. C, Crotaria retusa L., Chromolaena odorata (L) King and Robinson, Panicum maximum L. and Cyperus esculentus L. also inhibited seed germination of Zea mays L., Citrullus lanatus Thunb, Abelmoschus esculentus (L) Moench, Glycine max (L) Men and Arachis hypogea L. (Usuah et al., 2013).

The inhibition of germination of seeds of the plant extracts might be as a result of phytotoxic bio-active element which probably interfers with phytohormonal and enzymatic system of the seeds (Inderjit and Duke, 2003). This, invariably, impedes the physiological and biochemical processes necessary for germination.

Contrary to the above of maize and beans, the extract of Senna alata effect on groundnut shows improved germination rate. This observation is in line with the report of Agbagwa (2014) who reported that pre-soaked seeds of Celosia argentea in aqueous extract of $S$. alata shows improved germination and growth rate with increased concentration of the extract.

Crude aqueous leaf extract of $S$. alata induced considerable decrease in the absolute percentage and rate of germination of $Z$. mays, $P$. vulgaris and A. hypogea seeds over a 48 hour period. The germination rate and the percentage also fell significantly with increase in concentrations although the patterns lacks a definite trend as shown by Table 1, except in groundnut where the reverse is the case.

Contrary to the effect on seed germination, the extract of $S$. alata leaf caused increase $(\mathrm{P}<0.05)$ in the height and the dry weight of the seedling. (Table 2 and 3 ).

This stimulatory effect of plant extracts on growth of seedling was observed (Oudhia and Tripathi, 1997; Oudhia, 2001; Agbagwa, 2014). Similar report was made by Ben-Hammouda et al, (2001); who observed stimulation of seedling growth of wheat by barley extracts. Osuagwu (2007) also observed stimulation of seedling growth of cowpea and maize by leaf and stem extracts of Adenia lobata. Further study is needed to identify the bio-active phyto-toxin that inhibits germinations in $S$. alata extracts and the compound that improves growth in it.

From this, it can be deducted that leaf extract of Senna alata improves seedling growth with respect to height of maize, beans and groundnut.

4.2. Conclusion

Although the aqueous leaf extract of Senna alata tends to have stimulatory effects on the growth of seedling and tends to inhibit germination, when this effects were analysed using ANOVA, the difference was not significant.

It could be deducted that crude extract of Senna alata contains a bio active compound which is responsible for the inhibition of germination of seeds of maize, beans and groundnut. This bio active compound is also responsible for stimulatory effects on seedling growth of the mentioned crops.

\subsection{RECOMMENDATION}

Due to the stimulatory effect of Senna alata extract on seedling growth, it could be used as a bio fertilizer to stimulate growth in crops by local peasant farmers since its availability and low cost in processing is well established in the Nigerian local environment especially in the southern rain forest belt of the country.

In the same regard the aqueous extract of Senna alata could also be used as a growth retardant to prevent the germination of weed seeds in the field by local farmers, since it is biologically degradable and economically friendly.

I suggest also that more study should be made to ascertain the bio active compounds that are responsible for the inhibition on germination and stimulatory effects on seedling growth on crops.

\section{REFERENCES}

Agbagwa, I.O. (2014). Crude extracts of Senna alata [L] roxb mimics plant growth in promotion of vegetative and reproduction growth in Celosia argentia L. American Journal of Plant Sciences, 5: 1918-1925

Agrawal, R. L. (1995). Seed technology [2 $2^{\text {nd }}$ edition] oxford and IBH publishing co. PVT Ltd, New Delhi, India. Pp. 878

AL-lumaid, A. j and Warrang, M. O. A. (1998). Allelopathy effect of mesquite [Prosopis juliflora] foliage on seed germination and seedling growth of Bermuda Grass [Cynodon dactylon]. Journal of Arid Enviroment, 38:37234.

Ben-Hammouda, M., Ghorbal, H., Kremar, R. J. and Queslati, O. (2001). Allelopathic effect of barky extracts on 
germination and seedling growth of Bread and durum Wheat. Agronomie, 21, 65-71.

Erilisu, S. and Turkal, L. (1998). Allelopathic effect of juglome and walnut leaf extract on growth, fruit yield and plant tissue composition in strawberry Cultivars. J. Hortic. Sci Biotechnol, 80:39-42.

Evans, W. C., Trease and Evans (2002). Pharmacognosy. 15 ${ }^{\text {th }}$ ed. New Delhi: Reed Elsevier, India Pvt Ltd.

Gupta, G. L., and Ranal, A. C. (2007). Withania sominifera (Ashwaganda): A review. Pharmacogn Rev, 1:129136.

Hansen-quartey, J. A., Nyamapfene, K. and Materchera, S.A. (1988). Effect of Aqueous Extracts from Artemisia afra parts and soil on seed germination and early seedling development of selected plant species. South African Journal Plant Soil, 15 (4) 1-5.

Iqbal, Z., Furubayashi, A. and Fujii, T. (2001). Allelopathic effect of leaf debris leaf aqueous extract and rhizosphere soil of Ophiogon joponomicus Kergawler on the growth of plants. Blacks well synergy weed and Bio-management, 4 (1): 43-48.

Inderjit, K. and Duke, S. O (2003). Ecophysiological aspects of allelopathy. Planta, 217: 529-539.

Kruse, M. and Stradberg, B.(2000). Ecological effects of allelopathic plants. A review (NERI, Technical Report No. 315). Silkberg, Denmark; National Enviromental Research Institute.

Okwulehie, I.C. and Amazu, O.M., (2004). Possible allelopathic effects of Siam weed (Chromolaena odorata) (R.M. King and Robinson) extracts on the germination and seedling growth of cowpea (Vigna unguiculata) and Maize (Zea mays). Niger Agric J, 35: 59-67.

Osuagwu, G. G. E. and Ibeabuchi, I. C. (2010). The influence of aqueous leaf and stem extracts of Adenia lobata (Jacaq) on the flowering and fruiting of okra (Abelmoschus esculentus) and groundnut (Arachis hypogea). African journal of Biotechology, 9(22): 3260-3263.

Osuagwu, G. G. E. and Anyanwu, N. I. (2014). The effect of aqueous leaf and stem extracts of Senna alata (L.) Roxb. On the flowering and fruiting of okra (Abelmoschus esculentus). Journal of pharmacy and biological science, 9(5);70-73.

Oudhia, P. (2001). Allelopathic research on chickpea seeds in chhattishgarrh (India) region. An overview. Ecol. Envi and Cons, 7(1):31-35.

Oudhia, P. and Tripathi, R. S. (1997). Allelopathic potential of Calotropis gigantean. R.Br. World weeds, 4:109119.

Sahid, B. I and Sugau, J. B. (1993). Allelopathic effect of Lantana (Lantana camara) and Siam weed (Chromolena odorata) on selected crops. Weed science 41:303 - 308 .

Singh, G., Sharma, P. k., Dudhe, R. and Singh S. (2010). Biological activities of Withania sominiferia. Ann Biol Res, (1):56-63.

Torres, A., Olivia, R. M, Castellano, D. and Cross, P., (1996). First world congress on Allelopathy: a science of the future. Cadiz, Spain: SAI (University of Cardiz).

Usuah, P. E., Udom, G. N. and Edem, I. D. (2013). Allelopathic effect of some weeds on the germination seeds of selected crops grown in Akwa Ibom state, Nigeria. New world Journal of Agricultural Research, 1(4):59-64.

Alam, S. A., Ala, S. A., Azmi, A. R., Khan, M. A. and Ansari, R. (2001). Allelopathy and its role in agriculture. Online Journal of Biological Sciences, 1[5]:308-315.

Bisla, S. S., Nandal, D. P. S. and Narwal, S. S (1992). Influence of Aqueous Leaf extracts of Eucalyptus and Poplar on the germination and seedling growth of winter crops. Proceeding of the First National Symposium on Allelopathy in Agro-ecosystem. P. Tauro and Narwal S.S. \{eds.] IAS CCS Haryna. Agric. University, Hisar, India. Pp 3-97.

Clinton, B. D. and Vose, J. M (1996). Effect of Rhododendron maximum on Acerburum seedling establishing. Castanea, 61:38-45.

Der Marderosian, A. (2001). The review of natural products. St. Louis Missouri: Facts and comparisons.

Gawronska, H. and Golisz, A. (2006). Allelopathy and biotic stress in M.J. Reigossa, Pediol N. and Gonzalez L. (eds). Allelopathy: A physiology process with ecological Implications. Springer. The Netherlands. Pp 211227.

Hans, M. and Binadanda, M. (2008). Natural medicine in the tropics/foundation anamed. Winreden, Germany.

Hills, L. A. (1992). Candle bush Senna alata, Agonte weeds, branch, primary industry and fisheries, Northern territory of Australia, Darwin, Northern territory.

Jain, V.K. (2011). Fundamentals of plant physiology $14^{\text {th }}$ edition: S.Chard and Company: LTD, Ramvager, New Delhi-110055R. pp 663.

Navie, S.C (2004). Declared plants of Australia CD-ROM. The University of Queensland. 